\title{
Growth curve of pacu and the patinga hybrid farmed in a semi- intensive system
}

\section{Curva de crescimento do pacu e do híbrido patinga produzidos em sistema semi-intensivo}

\author{
Guilherme do Nascimento Seraphim"; Ruy Alberto Caetano Corrêa Filho²; André \\ Luiz Nunes ${ }^{3}$; Luana Barbosa Pires ${ }^{4}$; Thiago Gonsalo da Silva ${ }^{5}$; Yasmin Avila \\ Ferreira $^{6}$; Lucas Carvalho de Almeida ${ }^{6}$; Thiago Xavier Martins ${ }^{1}$; Nelson Mauricio \\ Lopera-Barrero $^{7}$; Louise Nex Spica ${ }^{8}$ J Jayme Aparecido Povh ${ }^{2 *}$
}

\section{Highlights:}

The patinga hybrid showed a final weight similar to that of pacu in a semi-intensive production system. The growth curve of the patinga hybrid for weight and morphometric traits was similar to that of pacu. The Gompertz model adequately fit the pacu and patinga growth curves.

\begin{abstract}
The growth curve is a tool that can be used to determine the performance potential of fish at different ages. The aim of this study was to evaluate the growth curve of pacu (P. mesopotamicus) and the patinga hybrid (P. mesopotamicus $\times$ P. brachypomus) cultivated in a semi-intensive system. In the initial phase of the experiment, the pacu and patinga fish weighed $32.6 \pm 7.5 \mathrm{~g}$ and $24.9 \pm 7.1 \mathrm{~g}$, respectively. The Gompertz model was adopted to describe the growth curve. At the end of the experiment, body weight, standard length, head length, body height and body width did not differ significantly between the pacu $(625.9 \mathrm{~g} ; 25.6 \mathrm{~cm} ; 7.2 \mathrm{~cm} ; 12.1 \mathrm{~cm} ; 4.5 \mathrm{~cm})$ and the patinga hybrid $(727.1 \mathrm{~g} ; 27.3 \mathrm{~cm} ; 7.6 \mathrm{~cm} ; 13.2$ $\mathrm{cm} ; 4.9 \mathrm{~cm}$ ). The asymptotic value (parameter A), relative growth rate (parameter B), and age at the inflection point (parameter $\mathrm{C}$ ) of the growth curve of the two species were similar for weight and for the evaluated morphometric traits. The asymptotic values obtained for weight in the pacu and the patinga hybrid were $1212.0 \mathrm{~g}$ and $1348.0 \mathrm{~g}$, respectively. The growth curve of the patinga hybrid is similar to that of pacu, contrasting with the belief of many fish farmers.
\end{abstract}

Key words: Asymptotic value. Gompertz model. Hybrid fish. Piaractus. Specific growth rate.

\footnotetext{
1 Mestres, Programa de Pós-Graduação em Ciência Animal, Faculdade de Medicina Veterinária e Zootecnia, Universidade Federal de Mato Grosso do Sul, FAMEZ/UFMS, Campo Grande, MS, Brasil. E-mail: guilherme.seraphim@hotmail.com; thiago.xavier. martins@hotmail.com

2 Profs. Drs., FAMEZ/UFMS, Campo Grande, MS, Brasil. E-mail: ruy.filho@ufms.br; jayme.povh@ufms.br

3 Dr., Programa de Pós-Graduação Ciência Animal, FAMEZ/UFMS, Campo Grande, MS, Brasil. E-mail: andre_lnunes@hotmail. com

4 Discente do Curso de Doutorado do Programa de Pós-Graduação Ciência Animal, FAMEZ/UFMS, Campo Grande, MS, Brasil. E-mail: luana.bio@hotmail.com

5 Médico Veterinário, FAMEZ/UFMS, Campo Grande, MS, Brasil. E-mail: thiagogonsalo@gmail.com

6 Zootecnistas, FAMEZ/UFMS, Campo Grande, MS, Brasil. E-mail: yasminavilaferreira@hotmail.com; lucas_9.7@hotmail.com

7 Prof. Dr., Departamento de Zootecnia, Universidade Estadual de Londrina, UEL, Londrina, PR, Brasil. E-mail: nmlopera@uel.br

8 Discente do Curso de Mestrado do Programa de Pós-Graduação Ciência Animal, FAMEZ/UFMS, Campo Grande, MS, Brasil. E-mail: louise.nex@gmail.com

* Author for correspondence
} 


\section{Resumo}

A curva de crescimento possibilita determinar o potencial de desempenho dos peixes em diferentes idades. O objetivo do estudo foi avaliar a curva de crescimento do pacu (P. mesopotamicus) e do híbrido patinga (P. mesopotamicus x P. brachypomus) produzidos em sistema semi-intensivo. Foram utilizados no início do experimento pacu e patinga com peso de $32,6 \pm 7,5 \mathrm{~g}$ e 24,9 \pm 7,1 g, respectivamente. Foi utilizado o modelo Gompertz para descrever a curva de crescimento. No final do experimento, o peso corporal, comprimento padrão, comprimento da cabeça, altura do corpo e largura do corpo não diferiram significativamente entre o pacu $(625,9 \mathrm{~g} ; 25,6 \mathrm{~cm} ; 7,2 \mathrm{~cm} ; 12,1 \mathrm{~cm} ; 4,5 \mathrm{~cm})$ e o híbrido patinga $(727,1$ g; $27,3 \mathrm{~cm} ; 7,6 \mathrm{~cm} ; 13,2 \mathrm{~cm} ; 4,9 \mathrm{~cm}$ ). O valor assintótico (parâmetro A), taxa de crescimento relativo (parâmetro B) e idade no ponto de inflexão (parâmetro C) da curva de crescimento do pacu e patinga foram semelhantes para peso e características morfométricas avaliadas. O valor assintótico obtido para peso no pacu e no híbrido patinga foi de $1212,0 \mathrm{~g}$ e 1348,0 g, respectivamente. O híbrido patinga apresenta curva de crescimento semelhante ao pacu, contrastando com a crença de muitos piscicultores. Palavras-chave: Valor assintótico. Modelo Gompertz. Peixe híbrido. Piaractus. Taxa de crescimento específico.

\section{Introduction}

Aquaculture production in Brazil is represented mainly by fish, with a total of 519,000 t produced in 2018 (Instituto Brasileiro de Geografia e Estatística [IBGE], 2020). The tambaqui (Colossoma macropomum), pacu (Piaractus mesopotamicus) and pirapitinga (Piaractus brachypomus) species and the tambacu (female C. macropomum $\times$ male $P$. mesopotamicus), tambatinga (female $C$. macropomum $\times$ male $P$. brachypomus) and patinga (female $P$. mesopotamicus $\times$ male $P$. brachypomus) hybrids are commonly placed in the group called 'round fish'. In 2018, this group corresponded to the second largest aquaculture production in Brazil, accounting for $30.2 \%$ of the total (IBGE, 2020).

Pacu is one of the most studied and reared fish species in Brazil and other South American countries (Abimorad et al., 2014). Originating from the Paraná, Paraguay and Uruguay river basins, the species has remarkable characteristics such as good production performance, hardiness and high meat quality (Urbinati \& Gonçalves, 2013). Pacu tolerates low-temperature conditions better than other species of round fish, which makes them more suitable for production in certain regions of Brazil.

Pirapitinga is native to the Solimões-Amazonas and Orinoco rivers and has characteristics similar to those of pacu (Vásquez-Torres, 2013). However, this species has been widely exploited for the production of the tambatinga and patinga hybrids (IBGE, 2020). These hybrids have gained prominence in Brazilian fish farming due mainly to the inexistence of selectively bred native species (Resende, 2009; Oliveira, Ribeiro, Streit, Povh, \& Resende, 2012; Fantini et al., 2017), which has led producers to exploit heterosis empirically.

The growth curve that best characterizes animal growth has a sigmoid shape, where the growth occurring during the first phase of life is slow, followed by a period of self-acceleration until reaching the maximum point of the growth rate (puberty), and then a period of self-deceleration (Fialho, 1999). The curve can be used to detect the growth potential and production performance of different fish (Fantini et al., 2019). In this regard, the Gompertz model has been used to describe the growth of fish such as Nile tilapia (Oreochromis niloticus) (Oliveira et al., 2013) and tambaqui (Mello et al., 2015).

The aim of this study was to evaluate the growth curve of pacu (Piaractus mesopotamicus) and the patinga hybrid ( $P$. mesopotamicus $\times P$. brachypoomus) farmed in a semi-intensive system. 


\section{Materials and Methods}

\section{Experimental sites and animals}

The experiment was carried out in the Fish Farming Section of the Federal University of Mato Grosso do Sul (UFMS) (20²9'58.7' S; 54³6'53.5” W), located in Campo Grande - MS, Brazil. Pacu and patinga fish were acquired from a commercial fish farm at initial weights of $32.6 \pm 7.5 \mathrm{~g}$ (pacu) and $24.9 \pm 7.1 \mathrm{~g}$ (patinga) and 83 days of age. These fish were allocated to the experimental units and cultivated for 295 days. The research was approved by the Ethics Committee on Animal Use (approval no. 785-2016 - CEUA UFMS).

\section{Experimental units and measured traits}

The fish were adapted to the environment for 15 days in hapas measuring $1.0 \mathrm{~m}^{3}$. After this period, they were identified with a microchip and distributed into three $100-\mathrm{m}^{2}$ excavated ponds where they were cultivated in a semi-intensive system with a waterexchange rate of $30 \%$ per day. Each excavated pond housed 50 fish of each genetic group, totaling 100 fish.
Nine biometric measurementss were carried out in the period of 295 days - the first immediately after the end of the fish adaptation period and the others at intervals of 32 or 33 days. To reduce the stress from handling, the fish were anesthetized with eugenol at $50 \mathrm{mg} \mathrm{L}^{-1}$ (Inoue, Boijink, Ribeiro, Silva, \& Affonso, 2011). Prior to the measurements, the fish were deprived of feed for $24 \mathrm{~h}$ for the determination of body weight $(\mathrm{g})$ and the following morphometric measurements $(\mathrm{cm})$ : standard length, head length, body height and body width.

\section{Feeding and water analysis}

The fish were fed an extruded commercial feed ( $28 \%$ crude protein, $5 \%$ ether extract, $6 \%$ crude fiber, $12 \%$ mineral matter and $87 \%$ dry matter) that was supplied twice daily (09h00 and 16h00), to apparent satiety. During the experimental period, the water characteristics were measured daily. Temperature, dissolved oxygen and $\mathrm{pH}$ were analyzed using a multi-parameter instrument (Professional Plus, YSI Incorporated, Yellow Springs, OH, USA). These variables were measured daily in the morning and afternoon. Monthly means of these water attributes were represented in a graph (Figure 1).

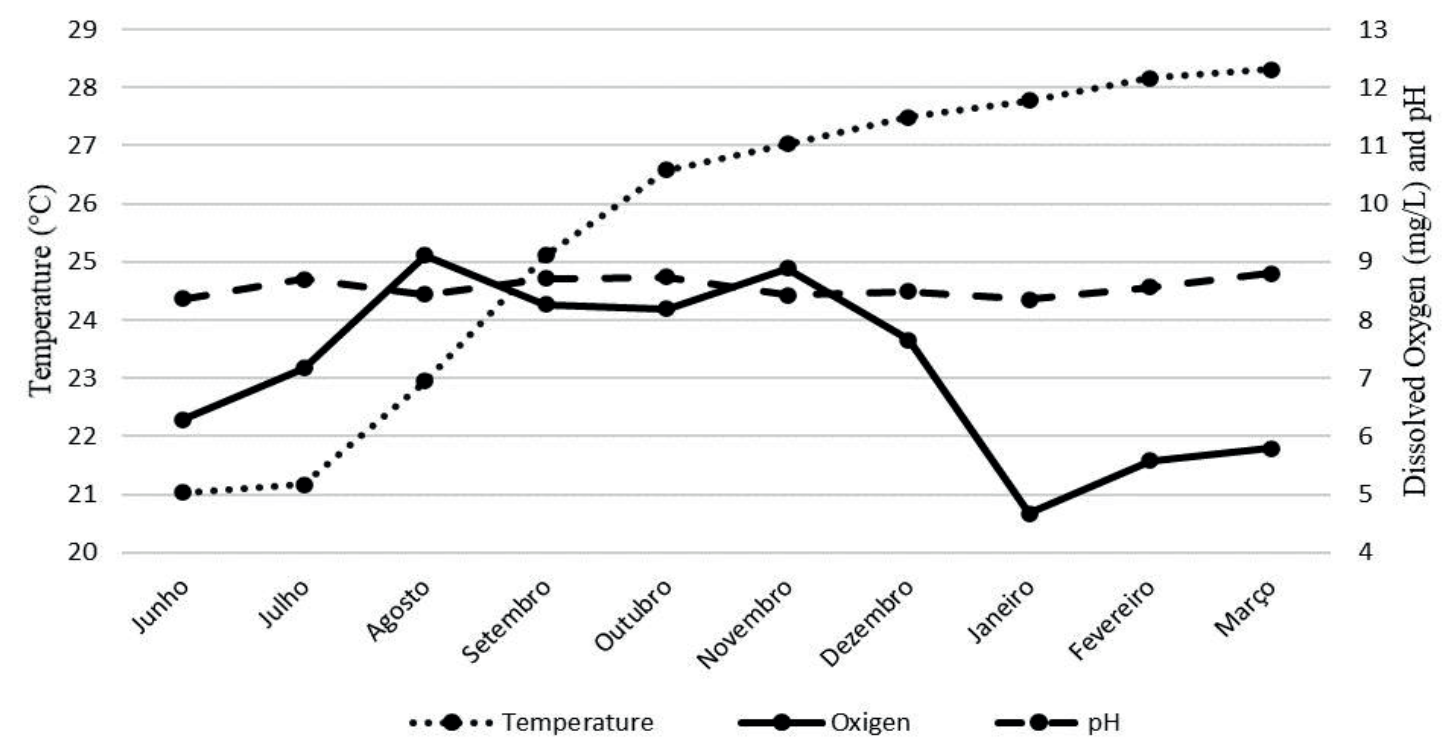

Figure 1. Mean values for temperature $\left({ }^{\circ} \mathrm{C}\right)$, dissolved oxygen $\left(\mathrm{mg} \mathrm{L}^{-1}\right)$, and $\mathrm{pH}$ of the water during the experimental period of evaluation of pacu ( $P$. mesopotamicus) and patinga ( $P$. mesopotamicus $\times P$. brachypomus) cultivated in excavated ponds for 295 days. 


\section{Statistical analysis and growth curves}

The data obtained from all biometric measurements were subjected to analyses of variance, in which the genetic group and the excavated pond were considered the factors and the weight in the first measurement was assumed as a co-variable. After analysis of variance at the $5 \%$ significance level, least-square means were calculated for the fitting of the growth curves. The analyses were carried out using the GLM procedure of SAS statistical software version 9.1.

Gompertz' non-linear regression model (Fialho, 1999) was used to describe the growth curve of the genetic groups (pacu and patinga), by the following equation:

$$
y_{i}=A \cdot e^{-e^{-B \cdot(t-C)}}
$$

where:

$y i$ - weight $(\mathrm{g})$ or size $(\mathrm{cm})$ of family $i$ estimated for age $t$;
$A$ - asymptotic weight $(\mathrm{g})$ or size $(\mathrm{cm})$ when $\mathrm{t}$ tends to plus infinite; i.e., this parameter may be interpreted as weight or size when growth ceases;

$B$ - relative growth at the inflection point ( $\mathrm{g} \mathrm{day}^{-1}$ per $\mathrm{g}$ of fish or $\mathrm{cm} \mathrm{day}^{-1}$ per $\mathrm{cm}$ of fish);

$$
\begin{aligned}
& C \text { - age at the inflection point (days); } \\
& t \text { - age (days); and } \\
& e-2.718281828459 .
\end{aligned}
$$

Gompertz' non-linear regression model was fitted to the least-square means obtained for each group at each age. The curve parameters were estimated using the NLIN procedure by the Marquardt method. To compare the growth curves, the models described in Table 1 were evaluated. To test the equality of parameters and the identity of non-linear models, the likelihood ratio test was applied with approximation given by the chi-square statistics, according to Regazzi and Silva (2004) (Table 1). SAS software version 9.1 was used for the analyses.

Table 1

Synthetic description of the eight Gompertz models (M) to compare the growth curves of pacu (Piaractus mesopotamicus) and the patinga hybrid (P. mesopotamicus $\times$ P. brachypomus) cultivated in excavated ponds for 295 days

\begin{tabular}{ccccccccc}
\hline Parameter & M1 & M2 & M3 & M4 & M5 & M6 & M7 & M8 \\
\hline $\mathrm{A}$ & $\mathrm{Ai}$ & $\mathrm{A}$ & $\mathrm{Ai}$ & $\mathrm{Ai}$ & $\mathrm{A}$ & $\mathrm{A}$ & $\mathrm{Ai}$ & $\mathrm{A}$ \\
$\mathrm{B}$ & $\mathrm{Bi}$ & $\mathrm{Bi}$ & $\mathrm{B}$ & $\mathrm{Bi}$ & $\mathrm{B}$ & $\mathrm{Bi}$ & $\mathrm{B}$ & $\mathrm{B}$ \\
$\mathrm{C}$ & $\mathrm{Ci}$ & $\mathrm{Ci}$ & $\mathrm{Ci}$ & $\mathrm{C}$ & $\mathrm{Ci}$ & $\mathrm{C}$ & $\mathrm{C}$ & $\mathrm{C}$ \\
\hline
\end{tabular}

$\mathrm{i}=$ different parameters tested for pacu (Piaractus mesopotamicus) and patinga (P. mesopotamicus $\times$ P. brachypomus).

\section{Results and Discussion}

The average water temperature rose continuously from the start (June $2016-21.0^{\circ} \mathrm{C}$ ) to the end of the experiment (March $2017-28.3^{\circ} \mathrm{C}$ ) (Figure 1). In the first months, water temperature was below the level recommended by Boyd (1998) for tropical fish, but remained adequate thereafter. The lower temperature observed at the beginning of the experiment might have influenced the growth curves of both groups, since it was below the ideal range.

The dissolved oxygen content in the water fluctuated considerably throughout the trial (4.7 $\mathrm{mg} \mathrm{L}^{-1}$ in January 2017 and $9.1 \mathrm{mg} \mathrm{L}^{-1}$ in August 2016). At the beginning and end of the experiment, 
dissolved oxygen values were 6.3 and $5.8 \mathrm{mg} \mathrm{L}^{-1}$, respectively. The water $\mathrm{pH}$ also changed over the course of the experiment, with peaks occurring at the start and end (8.4 and 8.8, respectively) (Figure 1). Both dissolved oxygen and $\mathrm{pH}$ remained within the range deemed adequate for tropical fish according to Boyd (1998).
At the start of the experiment (83 days of age), the fish biomass in the excavated pond was $0.03 \mathrm{~kg}$ $\mathrm{m}^{-2}$, which rose to $0.76 \mathrm{~kg} \mathrm{~m}^{-2}$ at the end (378 days of age). There was a small increase in biomass from June to September, when the water temperature was low (between 21.0 and $25.1^{\circ} \mathrm{C}$ ). Subsequently, a continuous biomass growth was seen as water temperature increased $\left(26.6^{\circ} \mathrm{C}\right)$ (Figure 2).

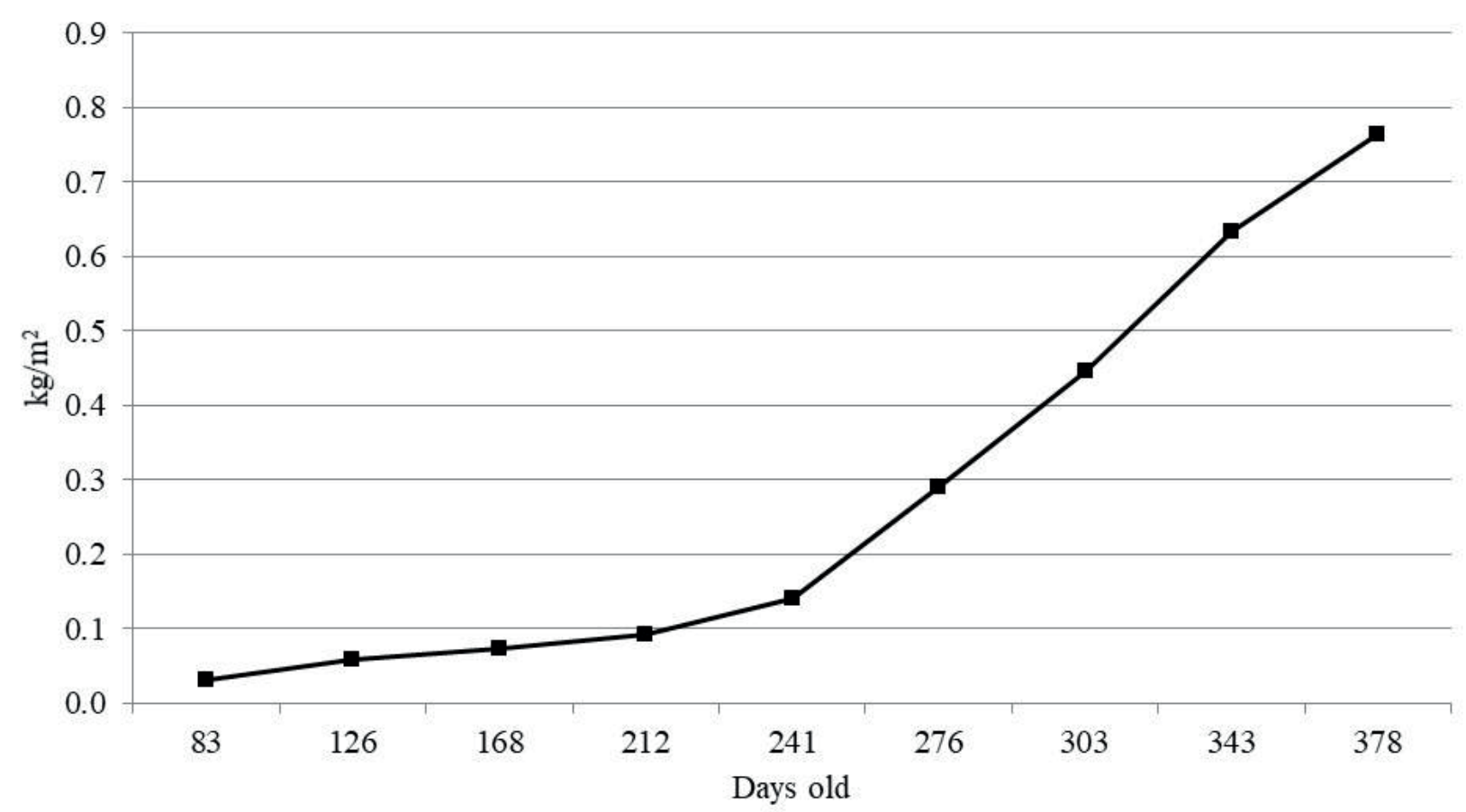

Figure 2. Final biomass $(\mathrm{kg})$ at the end of the experimental period of evaluation of the growth of pacu $(P$. mesopotamicus) and patinga (P. mesopotamicus $\times$ P. brachypomus) cultivated in excavated ponds for 295 days.

In a semi-intensive fish production system where the water-exchange rate is approximately $10 \%$ daily of the total volume, about $1 \mathrm{~kg}$ of fish can be produced per square meter (Ribeiro, 2001). Given that fish density was $0.76 \mathrm{~kg} \mathrm{~m}^{-2}(76.0 \mathrm{~kg}$ in $100 \mathrm{~m}^{2}$ ) at the end of the experiment, the carrying capacity of the excavated pond $(100 \mathrm{~kg})$ had not been reached, suggesting that the fish still had room to grow. However, final biomass was close to the carrying capacity of the excavated ponds.
Performance results pertaining to weight, standard length, head length, body height, and body width at the end of the experiment (295 days) were similar between the two genetic groups (Table 2). The best fit for the growth curves of weight and morphometric traits of pacu and patinga were achieved with model M8, where parameters A, B, and $\mathrm{C}$ are similar for both species (Table 3 ). 


\section{Table 2}

Least-squares means for body weight (BW), standard length (SL), head length (HL), body height (BH) and body width $(\mathrm{BW})$ of the pacu $(P$. mesopotamicus) and patinga $(P$. mesopotamicus $\times P$. brachypomus) genetic groups cultivated in excavated ponds for 295 days

\begin{tabular}{cccc}
\hline Trait & Pacu & Patinga & CV\% \\
\hline BW (g) & 625.9 & 727.1 & 14.4 \\
SL (cm) & 25.6 & 27.3 & 5.6 \\
HL (cm) & 7.2 & 7.6 & 8.9 \\
BH (cm) & 12.1 & 13.2 & 5.5 \\
BW (cm) & 4.5 & 4.9 & 12.1 \\
\hline
\end{tabular}

Variables similar to each other $(\mathrm{P}>0.05)$ according to the $\mathrm{F}$ test.

Table 3

Parameters of the best fitting Gompertz model (M8 - all parameters similar across genetic groups) obtained in the evaluation of the growth of the pacu (P. mesopotamicus) and patinga (P. mesopotamicus $\times$ P. brachypomus) genetic groups cultivated in excavated ponds for 295 days, for the body weight (BW), standard length (SL), head length (HL), body height (BH) and body width (BW) variables

\begin{tabular}{cccc}
\hline & & Full model* & \\
\hline Trait & Parameter & Pacu & Patinga \\
\hline BW & A & 1212.0 & 1348.0 \\
& B & 0.0073 & 0.0077 \\
& C & 321 & 315 \\
SL & A & 37.6 & 39.3 \\
& B & 0.0037 & 0.0044 \\
& C & 193 & 194 \\
HL & A & 11.6 & 12.2 \\
& B & 0.0032 & 0.0036 \\
BH & C & 223 & 224 \\
& A & 19.5 & 20.7 \\
& B & 0.0035 & 0.0041 \\
BW & C & 203 & 204 \\
& A & 6.7 & 7.1 \\
& B & 0.0035 & 0.0042 \\
\hline
\end{tabular}

A - asymptotic weight $(\mathrm{g})$ or length $(\mathrm{cm})$; B - relative growth at the inflection point ( $\mathrm{g}$ day ${ }^{-1}$ per $\mathrm{g}$ of fish or $\mathrm{cm} \mathrm{day}^{-1}$ per $\mathrm{cm}$ of fish); and $\mathrm{C}$ - age at the inflection point (days). *All parameters in all traits are similar to each other $(\mathrm{P}>0.05)$ according to the likelihood ratio test with approximation given by the chi-square statistics.

The final weight of the patinga hybrid was not higher than that of the pacu, which shows that the hybrid was not superior for that trait. This finding contrasts with the expected superiority of hybrid fish assumed by the production sector, considering the large production of hybrid species in recent years (2014, 2015, 2016, 2017 and 2018) in Brazil (IBGE, 2020). It should be stressed that, under different climatic conditions, as observed in different regions of Brazil, results distinct from those obtained in 
the present study may be observed. Therefore, inferences regarding the maintenance or superiority or inferiority in the performance of hybrid fish cannot be generalized for very different production situations.

The asymptotic value (parameter A) for weight did not differ between the pacu (1212.0 g) and the patinga hybrid $(1348.0 \mathrm{~g})$. The relative growth rate (parameter B) for weight was similar for the pacu (0.0073) and the patinga (0.0077). Likewise, the age at the inflection point (parameter $\mathrm{C}$ ) for weight was similar for both genetic groups (pacu - 321 days; patinga - 315 days) (Table 3; Figure 3).

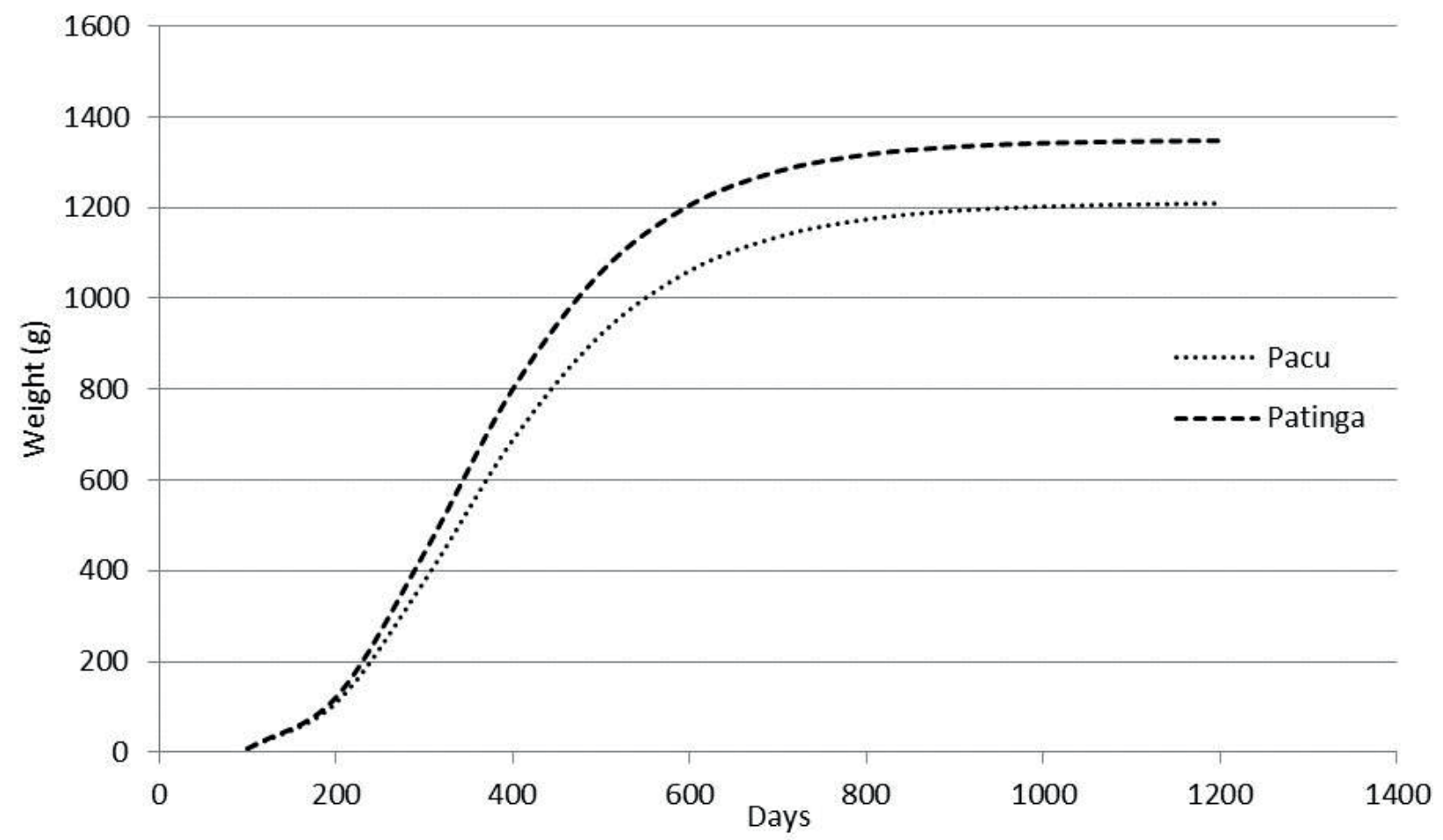

Figure 3. Growth curve for body weight (g) as a function of age (days), fitted by the Gompertz model, for the pacu (P. mesopotamicus) and patinga (P. mesopotamicus $\times$ P brachypomus) genetic groups cultivated in excavated ponds for 295 days.

The growth curve revealed that the asymptotic value for weight is observed only after the experimental period (295 days of experiment, 378 days of age), which was similar in both genetic groups. However, maintaining the fish in this system for more than 295 days of experiment would lead to a low asymptotic value for weight (1212.0 $\mathrm{g}$ for the pacu and $1348.0 \mathrm{~g}$ for the patinga), considering that the slaughter weight of those species is around $2000.0 \mathrm{~g}$.

Biomasses of 121.2 and $134.8 \mathrm{~kg}$ in $100 \mathrm{~m}^{-2}$ would be obtained in the excavated pond when the pacu and patinga reached the asymptotic weight, respectively. These values are considered high for a semi-intensive production system without oxygen supply in the water (Ribeiro, 2001). Higher asymptotic values by these two genetic groups could be obtained from the selective grading of the fish when the excavated ponds $\left(100 \mathrm{~m}^{2}\right)$ biomass reached $100 \mathrm{~kg}$.

Both species showed similar relative growth rates for weight, demonstrating that, at the age at the inflection point, growth was not changed with the cultivation of the hybrid fish, irrespective of 
the water temperature observed throughout the experiment. Moreover, the similarity in age at the inflection point for both species shows that the accelerated growth of the two was similar. Therefore, no earliness for growth was observed in the patinga hybrid in relation to the pacu.

For the standard length and head length traits, none of the parameters (A, B, and C) differed between the pacu and patinga genetic groups. Therefore, the asymptotic value, relative growth rate and age at the inflection point for these traits were similar between the genetic groups (Table 3; Figure 4; Figure 5). Similarly, the body height and body width measurements for the pacu and patinga genetic groups did not differ for any of the parameters (A, B, or C). Therefore, the asymptotic value, relative growth rate, and age at the inflection point for these traits were similar between the two species (Table 3; Figure 6; Figure7).

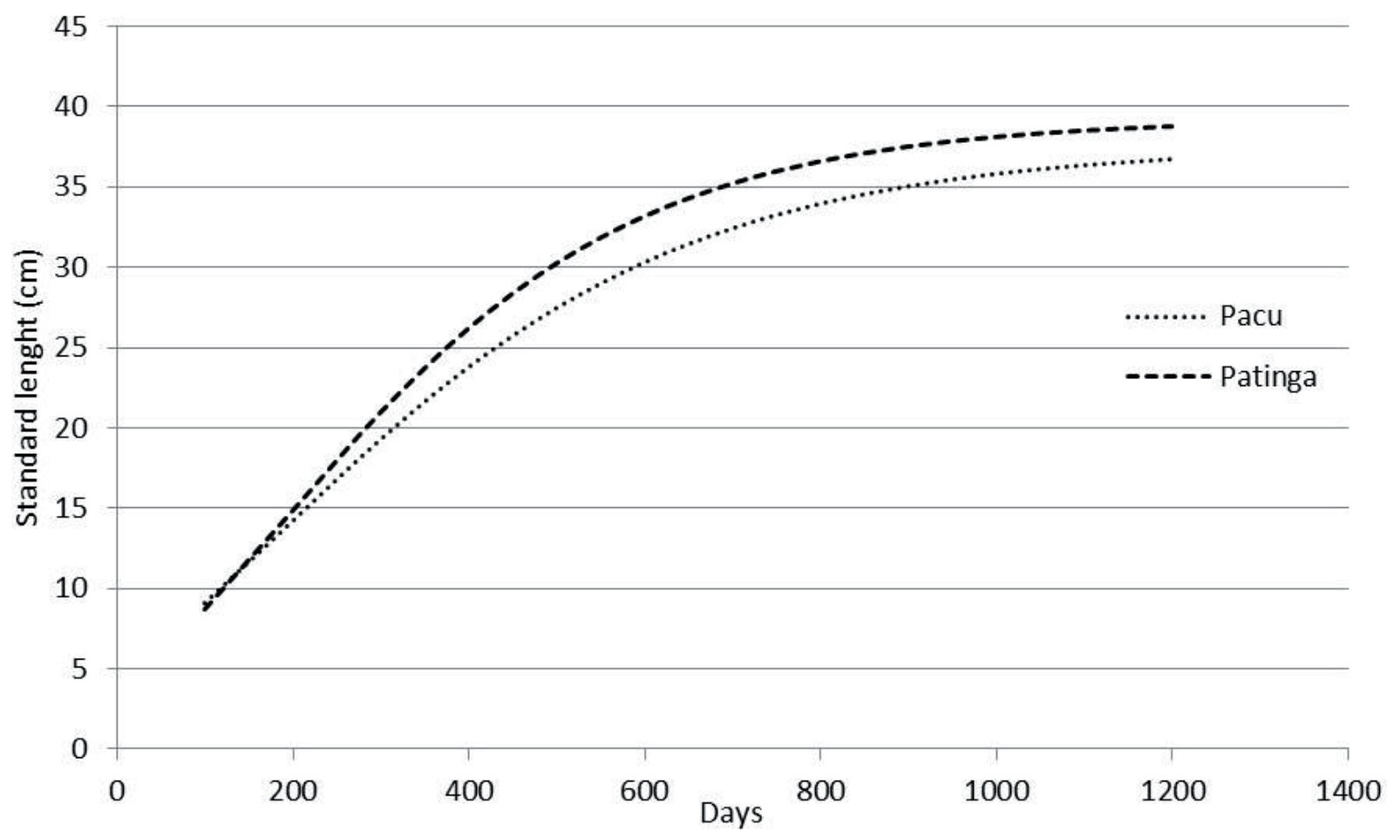

Figure 4. Growth curve for standard length $(\mathrm{cm})$ as a function of age (days), fitted by the Gompertz model, for the pacu (P. mesopotamicus) and patinga (P. mesopotamicus $\times$ P brachypomus) genetic groups cultivated in excavated ponds for 295 days. 


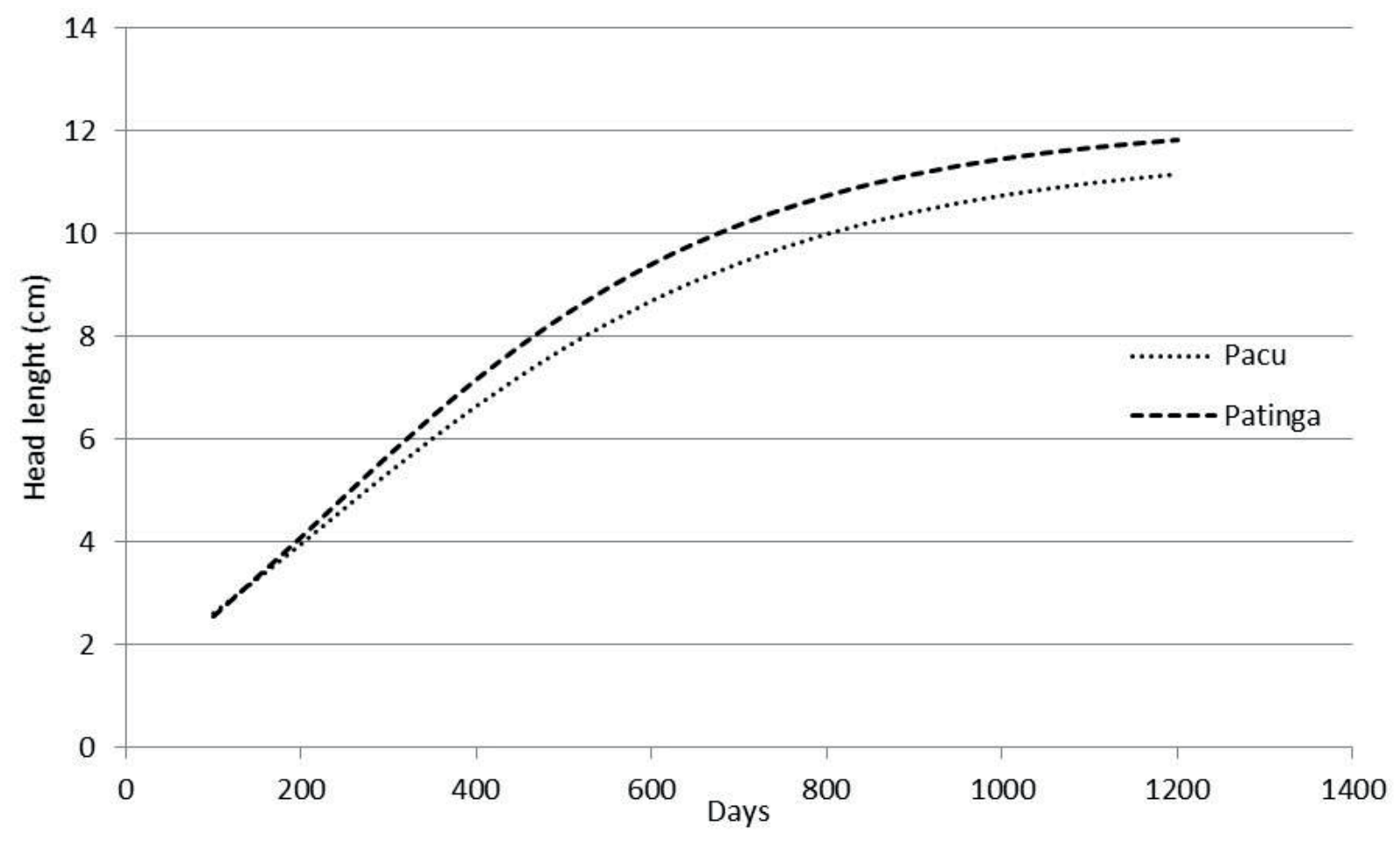

Figure 5. Growth curve for head length $(\mathrm{cm})$ as a function of age (days), fitted by the Gompertz model, for the pacu ( $P$. mesopotamicus) and patinga ( $P$. mesopotamicus $\times$ P brachypomus) genetic groups cultivated in excavated ponds for 295 days.

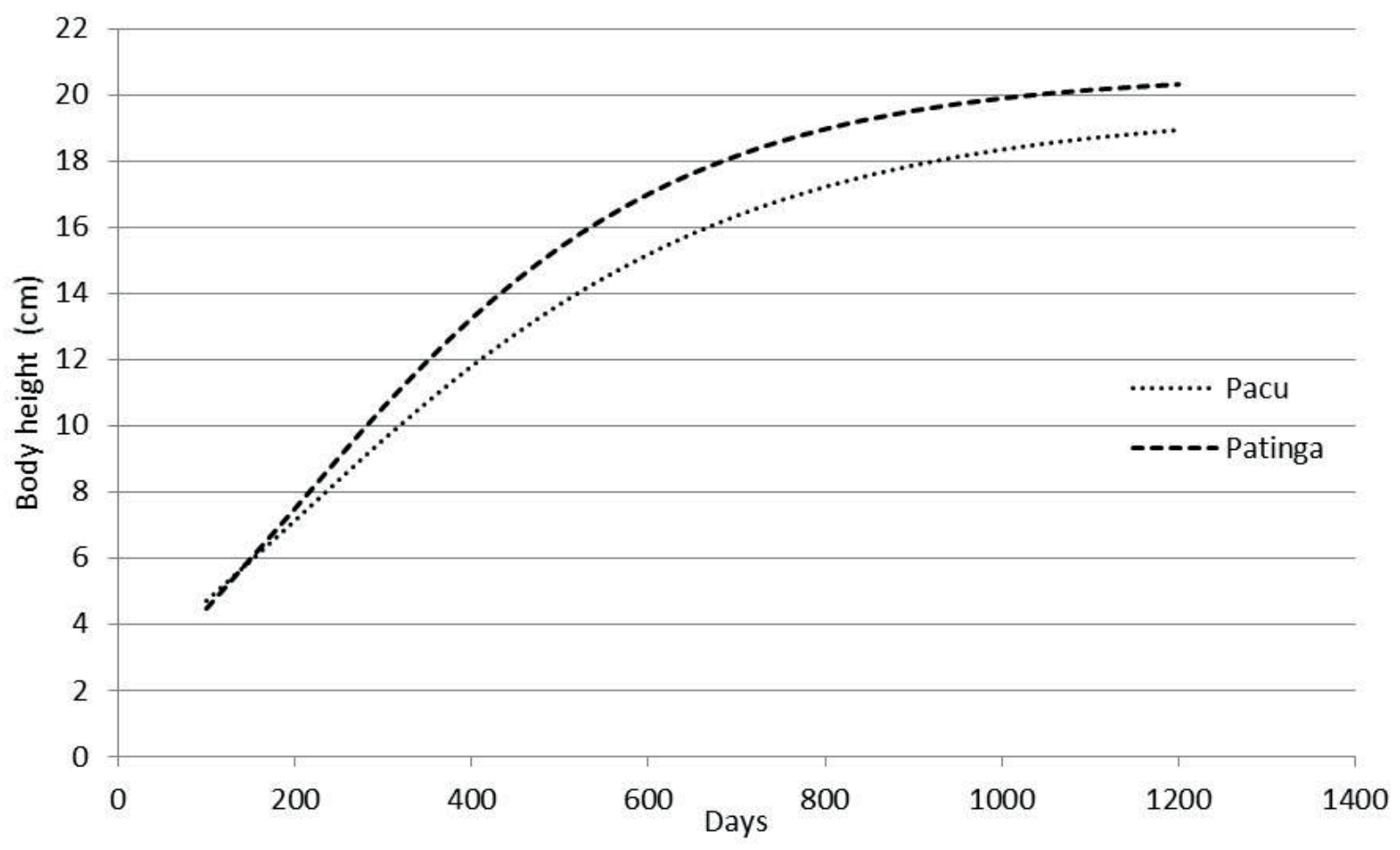

Figure 6. Growth curve for body height $(\mathrm{cm})$ as a function of age (days), fitted by the Gompertz model, for the pacu (P. mesopotamicus) and patinga (P. mesopotamicus $\times$ P brachypomus) genetic groups cultivated in excavated ponds for 295 days. 


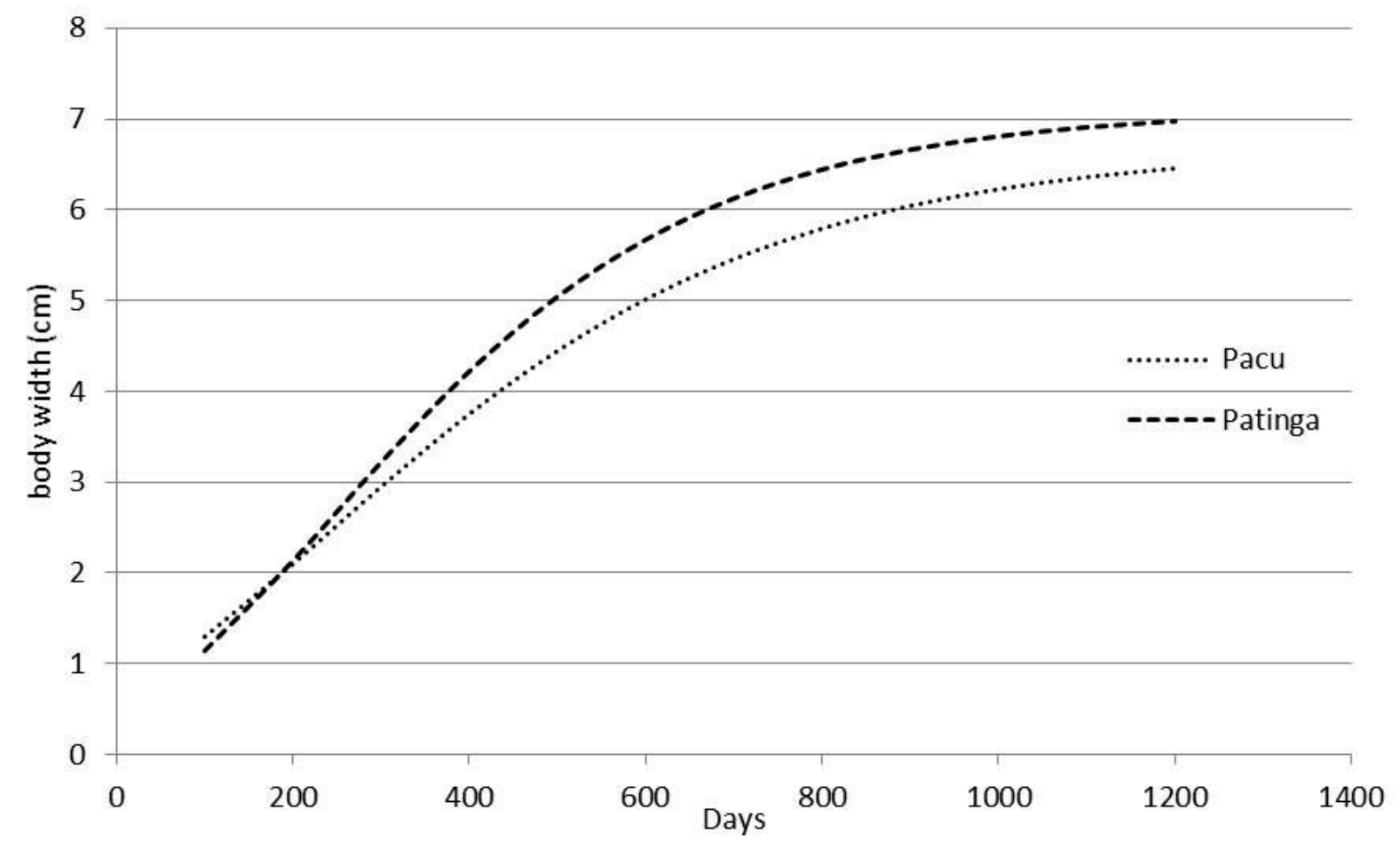

Figure 7. Growth curve for body width $(\mathrm{cm})$ as a function of age (days), fitted by the Gompertz model, for the pacu $(P$. mesopotamicus $)$ and patinga $(P$. mesopotamicus $\times P$ brachypomus $)$ genetic groups cultivated in excavated ponds for 295 days.

As seen for weight, the hybrid was also not superior for standard length at the end of the experiment (295 days of experiment). Interestingly, a great part of the maximum growth observed in the growth curve for standard lengths occurred at the end of the experiment, when the fish obtained $68.1 \%$ (pacu) and $69.5 \%$ (patinga) of the asymptotic value. This finding contrasted with that observed for weight, which, by the end of the experiment, represented 51.6 and $53.9 \%$ of the asymptotic value of the growth curve for the pacu, and patinga, respectively. A larger space might enable the pacu and patinga to have a higher asymptotic value for these traits, since this growth would be limited when the excavated pond reached its carrying capacity.

Both genetic groups displayed a similar age at the inflection point for standard length, which was lower than that observed for weight. This suggests that the accelerated growth of both genetic groups was earlier for that trait than for weight. Likewise, the relative growth rates for standard length were similar in both genetic groups, though with lower values than weight.

Head length, body height and body width were similar for both genetic groups at the end of the experiment and accounted for 62.1 to $69.0 \%$ of the asymptotic value of the growth curve. These results indicate that the growth of those measurements at the end of the experiment was higher than weight.

The relative growth rate and age at the inflection point for head length reveal that the patinga hybrid grew similarly to the pacu, in head size. Both genetic groups had lower head growth compared with the other morphometric measurements, considering that specific growth rate was lower and age at the inflection point was higher (i.e., a longer time to reach maximum growth) for head length in comparison with the other morphometric measurements, except body height, for which case age at the inflection point was higher. This result is 
appropriate for both genetic groups, since increased growth is undesirable for the head morphometric traits, which may have a direct impact on carcass yield (Vandeputte et al., 2017).

Lastly, the patinga hybrid did not display a greater growth for the evaluated traits in comparison with the pacu, under either lower (start of experiment) or higher (end of experiment) temperature conditions. This implies that the most appropriate means of improving performance is through selective breeding, a practice not commonly employed for tropical fish in Brazil (at present, the only species are Nile tilapia and tambaqui, the latter of which is still in the early stages of the program). Selective breeding programs for fish may provide genetic gains of around $15 \%$ per selection generation (Ponzoni, Hamzah, Tan, \& Kamaruzzaman, 2005; Ponzoni et al., 2011; Marcos et al., 2016; Nguyen, 2016), while heterosis is still restricted to one generation, only.

\section{Conclusions}

The pacu and patinga genetic groups have similar growth curves in a semi-intensive production system.

\section{Acknowledgments}

This study was financed in part by the Coordenação de Aperfeiçoamento de Pessoal de Nível Superior - Brasil (CAPES) - Finance Code 001 Brasil (CAPES); Fundação de Apoio ao Desenvolvimento do Ensino, Ciência e Tecnologia do Estado de Mato Grosso do Sul (FUNDECT 59-300.333-2015); Universidade Federal de Mato Grosso do Sul (UFMS); and Conselho Nacional de Desenvolvimento Científico e Tecnológico (CNPq).

\section{References}

Abimorad, E. G., Ducatti, C., Castellani, D., Jomori, R. K., Portella, M. C., \& Carneiro, D. J. (2014). The use of stable isotopes to investigate the effects of supplemental lysine and methionine on protein turnover and amino acid utilization in pacu, Piaractus mesopotamicus, juveniles. Aquaculture, 433(20), 119-124. doi: 10.1016/j.aquaculture.2014.06.006

Boyd, C. E. (1998). Water quality for pond aquaculture. Auburn: Auburn University.

Fantini, L. E., Corrêa, R. A. C., Fo., Martins, T. X., Laice, M. L., Seraphim, G. N., Silva, A. L.,... Povh, J. A. (2019). Growth curve comparison of native fish cachara (Pseudoplatystoma reticulatum) and cachapinta hybrid ( $P$. reticulatum $\times$ Pseudoplatystoma corruscans). Aquaculture, 506, 70-74. doi: 10.1016/j. aquaculture.2019.03.020

Fantini, L. E., Kinjo, G. N., Jr., Pereira, R. S., Pires, L. B., Corrêa, R. A. C., Fº, Povh, \& J. A. (2017). Production performance of cachara and hybrid cachapinta. Boletim do Instituto de Pesca, 44(Esp.), 107-112. doi: 10.20950/1678-2305.2017.107.112

Fialho, F. B. (1999). Interpretação da curva de crescimento de Gompertz. Concórdia: EMBRAPACNPSA.

Inoue, L. A. K. A., Boijink, C. L., Ribeiro, P. T., Silva, A. M. D., \& Affonso, E. G. (2011). Avaliação de respostas metabólicas do tambaqui exposto ao eugenol em banhos anestésicos. Acta Amazônica, 41(2), 327-342.

Instituto Brasileiro de Geografia e Estatística (2020). Produção de aquicultura. Recuperado de http://www. sidra.ibge. gov.br/bda/tabela/listabl.asp? $=3940$ $\& \mathrm{z}=\mathrm{t} \& \mathrm{O}=21$

Marcos, R., Povh, J. A., Fornari, D. C., Oliveira, C. A. L., Ribeiro, R. P., Lopera-Barrero, N. M., \& Murari, P. J. F. (2016). Weight gain and morphometric growth of genetically improved tambaqui (Colossoma macropomum). Semina: Ciências Agrárias, 37(4), 2521-2528. doi: 10.5433/1679-0359.2016v37n4 Sup11p2521

Mello, F., Oliveira, C. A. L., Ribeiro, R. P., Resende, E. K., Povh, J. A., Fornari, D. C.,... Streit, D. P., Jr. (2015). Growth curve by Gompertz nonlinear regression model in female and males in tambaqui (Colossoma macropomum). Anais da Academia Brasileira de Ciências, 87(4), 2309-2315. doi: 10. 1590/0001-3765201520140315

Nguyen, N. H. (2016). Genetic improvement for important farmed aquaculture species with a reference to carp, tilapia and prawns in Asia: achievements, lessons and challenges. Fish and Fisheries, 17(2), 483-506. doi: 10.1111/faf.12122 
Oliveira, C. A. L., Ribeiro, R. P., Streit, D. P., Jr., Povh, J. A., \& Resende, E. K. (2012). Melhoramento genético de peixes, uma realidade para a piscicultura brasileira. Panorama da Aquicultura, 22(139), 3847.

Oliveira, A. M. S., Oliveira, C. A. L., Matsubara, B. J. A., Oliveira, S. N., Kunita, N. M., Yoshida, G. M., \& Ribeiro, R. P. (2013). Padrões de crescimento de machos e fêmeas de tilápias do Nilo (Oreochromis niloticus) da variedade GIFT. Semina: Ciências Agrárias, 34(4), 1891-1900. doi: 10.5433/16790359. 2013v34n4p1891

Ponzoni, R. W., Hamzah, A., Tan, S., \& Kamaruzzaman, N. (2005). Genetic parameters and response for live weight in the GIFT strain of Nile tilapia (Oreochromis niloticus). Aquaculture, 247(1-4), 203-210. doi: 10.1016/j.aquaculture.2005.02.020

Ponzoni, R. W., Nguyen, N. H., Khaw, H. L., Hamzah, A., Bakar, K. R. A., \& Yee, H. Y. (2011). Genetic improvement of Nile tilapia (Oreochromis niloticus) with special reference to the work 367 conducted by the WorldFish Center with the GIFT strain. Aquaculture, 3(1), 27-41. doi: 10.1111/j.1753-5131. 2010.01041.x

Regazzi, A., \& Silva. C. (2004). Teste para verificar a igualdade de parâmetros e a identidade de modelos de regressão não-linear: I. Dados no delineamento inteiramente casualizado. Revista de Matemática e Estatística, 22(3), 33-45.
Resende, E. K. (2009). Pesquisa em rede em aquicultura: bases tecnológicas para o desenvolvimento sustentável da aquicultura no Brasil. Aquabrasil. Revista Brasileira de Zootecnia, 38(Supl. Esp.), 5257. doi: 10.1590/S1516-35982009001300006

Ribeiro, R. P. (2001). Construção de tanques. In H. L. M. Moreira, L. Vargas, R. P. Ribeiro, \& S. Zimmermann (Ed.), Fundamentos da moderna aquicultura (pp. 45-52). Canoas, RS: ULBRA.

Urbinati, E. C., \& Gonçalves, F. D. (2013). Pacu (Piaractus mesopotamicus). In B. Baldisserotto, \& L. C. Gomes (Ed.), Espécies nativas para piscicultura no Brasil (pp. 225-246). Santa Maria, RS: UFSM.

Vandeputte, M., Puledda, A., Tyran, A. S., Bestin, A., Coulombet, C., Bajek, A.,... Haffray, P. (2017). Investigation of morphological predictors of fillet and carcass yield in European sea bass (Dicentrarchus labrax) for application in selective breeding. Aquaculture, 470, 40-49. doi: 10.1016/j. aquaculture.2016.12.014

Vásquez-Torres, W. (2013). A pirapitinga, reprodução e cultivo. In B. Baldisserotto, \& L. C. Gomes (Ed.), Espécies nativas para piscicultura no Brasil (pp. 203-223). Santa Maria, RS: UFSM. 